\title{
Myocyte-Specific Enhancer Factor 2B
}

National Cancer Institute

\section{Source}

National Cancer Institute. Myocyte-Specific Enhancer Factor 2B. NCI Thesaurus. Code C92159.

Myocyte-specific enhancer factor 2B (365 aa, $239 \mathrm{kDa}$ ) is encoded by the human MEF2B gene. This protein is involved in transcription. 